\title{
Biosynthesis of indole-3-acetic acid via the indole-3-acetamide pathway in Streptomyces
} spp.

\author{
Shulamit Manulis, ${ }^{2}$ Hadas Shafrir, ${ }^{1}$ Ephraim Epstein, ${ }^{3}$ Amnon Lichter ${ }^{1}$ \\ and Isaac Barash ${ }^{1}$
}

Author for correspondence: Isaac Barash. Tel: +9723 6409847. Fax: +97236409380.

\footnotetext{
1 Department of Botany, Tel Aviv University, Tel Aviv 69978, Israel

2 Department of Plant Pathology and

3 Department of Horticulture, Agricultural Research Organization, The Volcani Centre, Bet Dagan 50250, israel
}

\begin{abstract}
Various Streptomyces spp. including S. violaceus, S. scabies, S. griseus, S. exfoliatus, S. coelicolor and S. lividans secrete indole-3-acetic acid (IAA) when fed with L-tryptophan (Trp). Production of IAA was detected in Streptomyces strains causing potato scab as well as in non-pathogenic strains. The pathways for IAA synthesis from Trp were investigated in S. violaceus and S. exfoliatus. Indole-3-acetamide (IAM), indole-3-lactic acid (ILA), indole-3-ethanol (IEt) and IAA were identified by HPLC and GC-MS. Streptomyces cells were capable of catabolizing IAM, ILA, IEt and indole-3-acetaldehyde (IAAId) into IAA. Incorporation of radioactivity into IAM, IAA and IAL but not IEt was detected when cells were fed with $L-\left[3-{ }^{14} \mathrm{C}\right]$ tryptophan. Results indicate the presence of the IAM pathway (Trp $\rightarrow$ IAM $\rightarrow$ IAA) and the possible presence of additional pathways for IAA biosynthesis in Streptomyces.
\end{abstract} Keywords: Streptomyces spp., indole-3-acetic acid, tryptophan, indole-3-acetamide
pathway

\section{INTRODUCTION}

The ability to produce the plant hormone indole-3-acetic acid (IAA) is widespread among micro-organisms that are commonly associated with plant surfaces (Wichner \& Libbert, 1968). IAA has been detected in plant pathogenic and non-pathogenic bacteria (Fett et al., 1987; Manulis et al., 1991; Badenoch-Jones et al., 1982; Tien et al., 1979; Barea \& Brown, 1974) as well as in mycorrhizal and other fungi (Ek et al., 1983; Gruen, 1959). IAA has been shown to be essential for gall formation by Pseudomonas syringae pv. salastanoi (Comai \& Kosuge, 1983) and Agrobacterium tumefaciens (Liv et al., 1982) and root induction by Agrobacterium rbizogenes (Offringa et al., 1986). Production of IAA from L-tryptophan (Trp) with indole-3-acetamide (IAM) as an intermediate (see Fig. 4) has been detected in gall-forming phytopathogenic bacteria (Van Onckelen $e t$ al., 1986; Comai \& Kosuge, 1983; Manulis et al., 1991), in Bradyrbizobium spp. (Sekine et al., 1988) and it may occur in other bacteria also (Fett $e$ t al., 1987). Although the IAM pathway has been recently demonstrated in higher plants (Kawaguchi et al., 1993; Saotome et al., 1993) its presence in plants might be rare. In contrast to the IAM pathway,

Abbreviations: IAA, indole-3-acetic acid; IAAld, indole-3-acetaldehyde; IAM, indole-3-acetamide; IEt, indole-3-ethanol; ILA, indole-3-lactic acid; IPvA, indole-3-pyruvic acid; Trp, tryptophan. the indolepyruvic acid (IPvA) route is quite common in many microbes and plants (e.g. Fett et al., 1987; Iskric, 1984).

Production of IAA by Streptomyces spp. has been reported previously (El-Shanshoury, 1991; El-Sayed et al., 1987; Hirata, 1959) although its identity was not rigorously confirmed by modern analytical methods. It has been suggested that IAA may act as an endogenous regulator of spore germination in Streptomyces atroolivaceus (ElShanshoury, 1991) and may be involved in differentiation of actinomycetes (Efremenkova et al., 1985). Streptomyces scabies (Hooker, 1981) as well as other Streptomyces spp. (Doering-Saad et al., 1992) have been reported as the causal agents of potato scab disease. The observation that development of potato scab formation is associated with cell division during development of wound periderm (Lapwood, 1973) may lead to the hypothesis that IAA is involved in pathogenicity of Streptomyces spp. The present study was undertaken to demonstrate the production of IAA by plant pathogenic and non-pathogenic Streptomyces strains and to characterize its biosynthetic pathway.

\section{METHODS}

Micro-organisms and growth conditions. The Streptomyces strains used in this study were as follows: $S$. violaceus (44, NP211, NP-214) and $S$. griseus $(20,26,42)$, isolated from scabby 
potatoes in Israel; S. scabies (RL 840170) and S. exfoliatus (RL 830103), obtained from R. Loria (Department of Plant Pathology, Cornell University, Ithaca, NY, USA). The identification of these strains according to numerical taxonomy was described by Doering-Saad et al. (1992). S. coelicolor M110 and S. lividans 1326 were obtained from H. Schrempf (Fachbereich Biologie/ Chemie, Universitat Osnabrück, Osnabrück, Germany). Strains were grown at $28^{\circ} \mathrm{C}$ on $\mathrm{R} 2$ agar medium without sucrose and maintained in glycerol at $-70^{\circ} \mathrm{C}$ as described by Hopwood et al. (1985).

Production and extraction of IAA and other indole derivatives. The routes for IAA biosynthesis from Trp were investigated by feeding a concentrated bacterial cell suspension with Trp or other indole derivatives and determining the metabolic intermediates released into the supernatant. Bacteria were grown in 11 Erlenmeyer flasks containing $200 \mathrm{ml}$ tryptic soy broth (TSB) (Hopwood et al., 1985) supplemented with $200 \mathrm{mg} \mathrm{Trp} \mathrm{l}^{-1}$. The cultures were grown on a rotary shaker at $28{ }^{\circ} \mathrm{C}$ for $7-10 \mathrm{~d}$. The cells were then centrifuged from the culture medium at $10000 \mathrm{~g}$ for $15 \mathrm{~min}$ at $4{ }^{\circ} \mathrm{C}$, washed with $0.01 \mathrm{M}$ phosphate buffered saline (PBS), $\mathrm{pH} 7.2$ and resuspended in the feeding solution. The experiment was carried out in $250 \mathrm{ml}$ Erlenmeyer flasks containing fresh cells $(25 \mathrm{~g})$ and feeding solution composed of: PBS, $2 \mathrm{mM}$; Tricine/KOH buffer (Sigma) pH 8.3, $30 \mathrm{mM}$; D-glucose, 2.5 mM; $\mathrm{MgSO}_{4}$, $0.2 \mathrm{mM}$; streptomycin, $50 \mu \mathrm{g} \mathrm{ml}^{-1}$; penicillin $50 \mu \mathrm{g} \mathrm{ml}^{-1}$, cetyltrimethylammonium bromide (CTAB), $2.7 \mathrm{mM}$; and Trp, $7.6 \mathrm{mM}$, or other indole derivatives $(2 \mathrm{mM})$, in a total volume of $90 \mathrm{ml}$. The viability of the bacterial cells was not affected by addition of the CTAB. All the chemicals and flasks were sterilized and the reaction mixture was prepared under aseptic conditions. Flasks were incubated at $28^{\circ} \mathrm{C}$ for $3 \mathrm{~d}$, in the dark on a rotary shaker, prior to the removal of the cells by centrifugation at $10000 \mathrm{~g}$ for $15 \mathrm{~min}$.

The supernatant was acidified to $\mathrm{pH} 3.0$ with $2 \mathrm{M} \mathrm{HCl}$ and extracted twice with equal volume of analytical ethyl acetate. The ethyl acetate extracts were pooled and flash-evaporated at $30^{\circ} \mathrm{C}$. The dry pellet was dissolved in $500 \mu \mathrm{l}$ methanol containing $1 \%$ butylated hydroxytoluene (BHT) and chromatographed on a silica gel $60 \mathrm{H}$ column $(2 \times 10 \mathrm{~cm})$. The column was washed three times with each of the following fractions of hexane/ethyl acetate (v/v): (I) $38: 12$, (II) $51: 24$, (III) $45: 30$. (IV) $33: 42$, (V) $21: 54$ and (VI) 12:60 with three parts of methanol and twice with $25 \mathrm{ml}$ of methanol. The various: fractions of each solvent were combined, reduced to dryness in vacuo and dissolved in $300 \mu \mathrm{l}$ methanol containing $1 \%$ BHT. The resultant solutions were analysed for the presence of indole metabolites. IAA and IEt were eluted in fraction I, indole lactic acid (ILA) was eluted in fraction IV and IAM and Trp were eluted in fraction VI.

Identification of indole metabolites. Initial identification of IAA and other indole derivatives was carried out by thin-layer chromatography (TLC) on $0.25 \mathrm{~mm}$ glass plates with authentic standards in either acidic or basic solvents: (A) chloroform/ethyl acetate/formic acid (35:55:10, by vol.); (B) ethyl acetate/propan-2-ol/ammonia ( $45: 35: 20$, by vol.). The plates were sprayed with Ehmann's reagent (Ehmann, 1977) followed by heating and washing with tap-water for intensification of the stained spots. Identification of IPvA and IAAld was carried out as described by Manulis et al. (1991).

Quantitative analysis of the various indoles was performed by high performance liquid chromatography (HPLC) in a Varicin 5000 chromatograph with a Rheodyne 7125 sample injector (50 $\mu$ l loop), a Varian UV-100 detector at $280 \mathrm{~nm}$, and a HewlettPackard $3390 \mathrm{~A}$ integrator. The indole compounds were applied
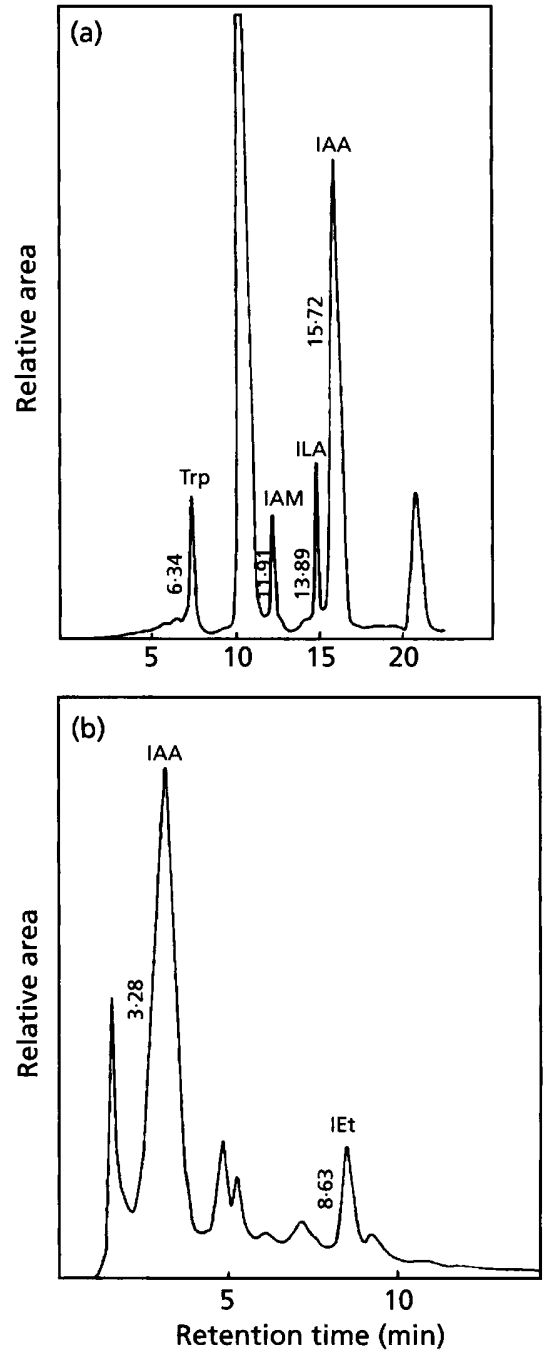

Fig. 1. Reverse-phase HPLC profile of indole derivatives produced by $S$. violaceus strain 44 . (a) Ethyl acetate extract of Trp-feeding solution was chromatographed on a silica gel $60 \mathrm{H}$ column as described in Methods. Eluted fractions I, IV and VI were combined, reduced to dryness and dissolved in $300 \mu \mathrm{l}$ methanol. Following injection $(50 \mu \mathrm{l})$, the column was eluted with a gradient of $10-90 \%(\mathrm{v} / \mathrm{v})$ methanol containing $0.1 \%$ acetic acid. (b) The same as (a) except that only fraction I (containing IAA and IEt) from the silica gel $60 \mathrm{H}$ column was injected and a gradient of $25-75 \%$ methanol containing $20 \mathrm{mM}$ ammonium acetate, $\mathrm{pH} 6.5$ was used.

to a Whatman ODSRP18 $(5 \mu \mathrm{m})$ column and eluted with a 35 min gradient of $10-90 \%(\mathrm{v} / \mathrm{v})$ methanol containing $0.1 \%$ acetic acid. Solvents were delivered at a flow rate of $1.5 \mathrm{ml} \mathrm{min}{ }^{-1}$. This solvent could separate IAA, IAM, ILA and Trp. Separation of IEt from IAA was achieved by employing a 20 min gradient of $25-75 \%$ methanol (v/v) containing $20 \mathrm{mM}$ ammonium acetate buffer, $\mathrm{pH}$ 6.5. Combined gas chromatography-mass spectrometry (GC-MS) was performed on a Finnigan MAT 4600 mass spectrometer as described by Manulis et al. (1991). The indole derivatives were purified by HPLC prior to GC-MS analysis.

Incorporation of labelled tryptophan into indole metabolites. $\mathrm{L}\left[3{ }^{14} \mathrm{C}\right]$ Tryptophan $\left[55.4 \mathrm{mCi} \mathrm{mmol}^{-1} \quad\left(2.05 \mathrm{GBq} \mathrm{mmol}^{-1}\right)\right]$ 


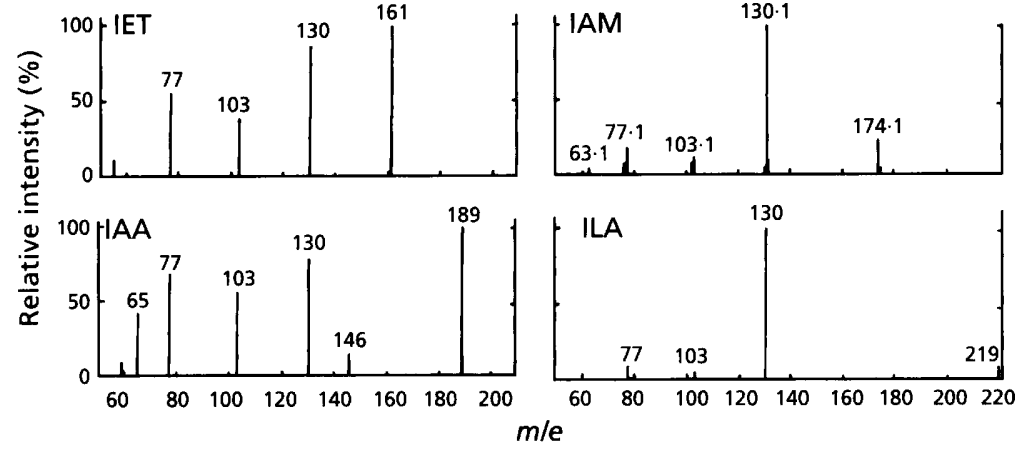

Fig. 2. Electron-impact mass spectra of the IEt, IAM, methyl IAA and ILA peaks obtained from HPLC (Fig. 1). The mass spectra presented are identical with those of authentic samples. was obtained from Amersham, and used for feeding experiments. Feeding of labelled Trp to bacterial cells was as described above except that only radioactive $\operatorname{Trp}$ was added at a final concentration of $1.6 \mathrm{mM}$ instead of $7.6 \mathrm{mM}$.

Identification of radioactive intermediates was based on cochromatography with authentic standards using the acidic and basic TLC solvents described above. The non-fluorescent TLC plates were dried and autoradiography was carried out at room temperature with Kodak XAR-5 film for $72 \mathrm{~h}$.

\section{RESULTS}

\section{Identification of indole derivatives}

Characterization of the indole metabolites was initially performed by co-chromatography of the ethyl acetate extract with authentic compounds on TCL in solvents A and B. After the plates had been sprayed with Ehmann's reagent, IAA, IAM, ILA, IEt and Trp appeared in solvent $A$ as blue spots with $R_{F}$ values of $0.75,0.61,0.5,0.7$ and $0 \cdot 04$, respectively, and in solvent $B$ with $R_{F}$ values of $0 \cdot 41$, $0.92,0.42,0.95$ and 0.32 , respectively. Attempts to detect IPvA and IAAld following their conversion into 2,4dinitrophenylhydrazones and chromatography on TLC gave negative results.

\section{Table 1. Release of indole metabolites by cell} suspensions of Streptomyces spp.

Concentrated cell suspensions were fed with tryptophan $(7.6 \mathrm{mM})$ under sterile conditions and the indole derivatives were extracted from the supernatant as described in Methods. Quantitative determination of the indole derivatives was carried out by HPLC. The concentration ranges of the various compounds indicating the minimum and maximum amounts were obtained from four different experiments.

\begin{tabular}{|ccc|}
\hline Indole derivative & $\begin{array}{c}\text { Concentration detected } \\
\left(\mu \mathrm{m} \mathrm{ml}^{-1}\right)\end{array}$ \\
\cline { 2 - 3 } & $\begin{array}{c}\text { S. violaceus } \\
\mathbf{( 4 4 )}\end{array}$ & $\begin{array}{c}\text { S. exfoliatus } \\
(\mathbf{R L ~ 8 3 0 1 0 3 )})\end{array}$ \\
\hline Indole-3-acetic acid & $10-30$ & $5-10$ \\
Indole-3-acetamide & $10-60$ & $5-10$ \\
Indole-3-ethanol & $10-30$ & $5-20$ \\
Indole-3-lactic acid & $10-50$ & $10-50$ \\
\hline
\end{tabular}

Further identification was achieved by fractionation of the various compounds on a silica gel column and injection of each fraction into an HPLC apparatus. Results presented in Fig. 1(a) show the detection of Trp, IAM, ILA and IAA with retention times of $6.34,11.91,13.89$ and $15 \cdot 72 \mathrm{~min}$, respectively, when the acidic methanol gradient was employed. Two other major peaks remained unidentified. Since IAA and IEt showed identical retention times with the acidic solvent, a basic methanol solvent was used for separating these compounds (Fig. 1b). The retention times for IAA and IEt were 3.28 and $8.63 \mathrm{~min}$, respectively. The mass spectra obtained from GC-MS for the HPLC peaks of IAA, IAM, ILA and IEt are illustrated in Fig. 2. They were identical to those obtained for authentic compounds. Quantitative estimation of the identified indole derivatives produced by $S$. violaceus strain 44 and S. exfoliatus strain RL 830103 after the cells were fed with Trp is summarized in Table 1 . The presence of a significant concentration of IAM and IAA in both species could suggest the existence of the IAM pathway (see Fig. 4).

\section{Metabolism of indole intermediates by cell suspensions}

The ability of concentrated bacterial cells to metabolize infiltrated indole intermediates into IAA could provide evidence for the presence of a metabolic pathway for IAA biosynthesis. These experiments were performed by permeating the cells with various indole derivatives and detecting the release of IAA into the supernatant. Results presented in Table 2 indicate that all the tested indole intermediates, namely IAM, IEt, ILA and IAAld were converted into IAA when incubated in the presence of cells of $S$. violaceus or $S$. exfoliatus. IPvA was not included in these experiments since a significant breakdown into IAA occurred even in the absence of bacterial cells. The traces of IAA in the supernatants of unfed cells (Table 2) probably originated from their internal IAA pool, which had accumulated during their prior growth in TSB medium supplemented with Trp.

\section{Metabolism of radioactive tryptophan into indole metabolites}

The results of feeding $S$. violaceus strain 44 with L-[3${ }^{14}$ C] tryptophan (Fig. 3) indicate incorporation of radioactivity into IAM, IAA and IAL. IEt, which had 
Table 2. Metabolism of indole derivatives into IAA by $S$. violaceus and $S$. exfoliatus

Concentrated cell suspensions were fed for $72 \mathrm{~h}$ with various indole derivatives $(2 \mathrm{mM})$ under sterile conditions and IAA was extracted from the supernatant and measured as described in Methods. Results presented were obtained from three different experiments.

\begin{tabular}{|c|c|c|}
\hline \multirow[t]{2}{*}{$\begin{array}{l}\text { Compound } \\
\text { added }\end{array}$} & \multicolumn{2}{|c|}{$\begin{array}{l}\text { IAA concentration } \\
\left(\mu \mathrm{g} \mathrm{ml}^{-1}\right)\end{array}$} \\
\hline & $\begin{array}{c}\text { S. violaceus } \\
(44)\end{array}$ & $\begin{array}{l}\text { S. exfoliatus } \\
\text { (RL 830103) }\end{array}$ \\
\hline Indole-3-acetamide & $11-17$ & $10-20$ \\
\hline Indole-3-ethanol & $10-25$ & $10-20$ \\
\hline Indole-3-lactic & $10-40$ & $10-40$ \\
\hline Indole-3-acetaldehyde & $10-25$ & $10-30$ \\
\hline No addition & $3-5$ & $3-5$ \\
\hline
\end{tabular}

A

\section{- IAM}

Fig. 3. Autoradiography of thin-layer chromatograph of indole derivatives produced by $S$. violaceus (strain 44) following incorporation of $\left[{ }^{14} \mathrm{C}\right] \mathrm{Trp}$. Experimental conditions are described in Methods. A and $B$ represent two separate experiments. In A, the chromatogram was developed in the basic solvent, in $B$ with the acidic solvent.
Table 3. Production of IAA by various Streptomyces spp.

Estimation of IAA was performed as described in Table 2. (+) indicates an IAA level of above $5 \mu \mathrm{g} \mathrm{ml}^{-1}$ in two different experiments. Characterization of the various Streptomyces strains and their pathogenicity was according to Doering-Saad $e t$ al. (1992).

\begin{tabular}{|llcc|}
\hline $\begin{array}{l}\text { Streptomyces } \\
\text { sp. }\end{array}$ & Strain & $\begin{array}{c}\text { Pathogenicity } \\
\text { on potato }\end{array}$ & $\begin{array}{c}\text { IAA } \\
\text { production }\end{array}$ \\
\hline S. violaceus & 44 & + & + \\
& NP 214 & - & + \\
& NP 211 & - & + \\
S. scabies & RL 840170 & + & + \\
S. griseus & 20 & + & + \\
& 26 & + & + \\
& 42 & + & + \\
S. exfoliatus & RL 830103 & + & + \\
S. coelicolor & S.MII0 & - & + \\
S. lividans & 1362 & - & + \\
\hline
\end{tabular}

previously been identified by GC-MS (Fig. 2), was not detected as a labelled compound under the experimental conditions used. A similar incorporation pattern of radioactive Trp into indole derivatives was obtained with S. exfoliatus (RL 830103).

\section{Production of IAA by various pathogenic and non- pathogenic Streptomyces strains}

Results presented in Table 3 suggest that IAA biosynthesis from Trp is widespread among different Streptomyces spp. and is not exclusive to strains which cause potato scab.

\section{DISCUSSION}

The ability of Streptomyces spp. to produce IAA in the presence of Trp may result from several biosynthetic pathways. The presence of the IAM pathway in $S$. violaceus and $S$. exfoliatus is supported by the following observations: (i) chemical identification of the indole intermediate, IAM, during catabolism of Trp into IAA; (ii) production of IAA following infiltration of the bacterial cells with IAM; and (iii) incorporation of radioactive carbon from Trp into IAM and IAA. This pathway appears to be prevalent in bacteria but seems to be quite rare in higher plants. It has been suggested (Manulis et al., 1991; Iskric, 1984) that by utilizing the IAM pathway pathogenic bacteria may override the regulatory mechanism through which plants that lack this pathway control the IAA level. In addition, the IAM pathway can detoxify several growth-inhibiting tryptophan analogues (Kosuge et al., 1985).

The detection of ILA and IEt and the ability of the Streptomyces cells to convert them into IAA may indicate the existence of additional pathways for IAA biosynthesis. These intermediates were also identified in other microbes 


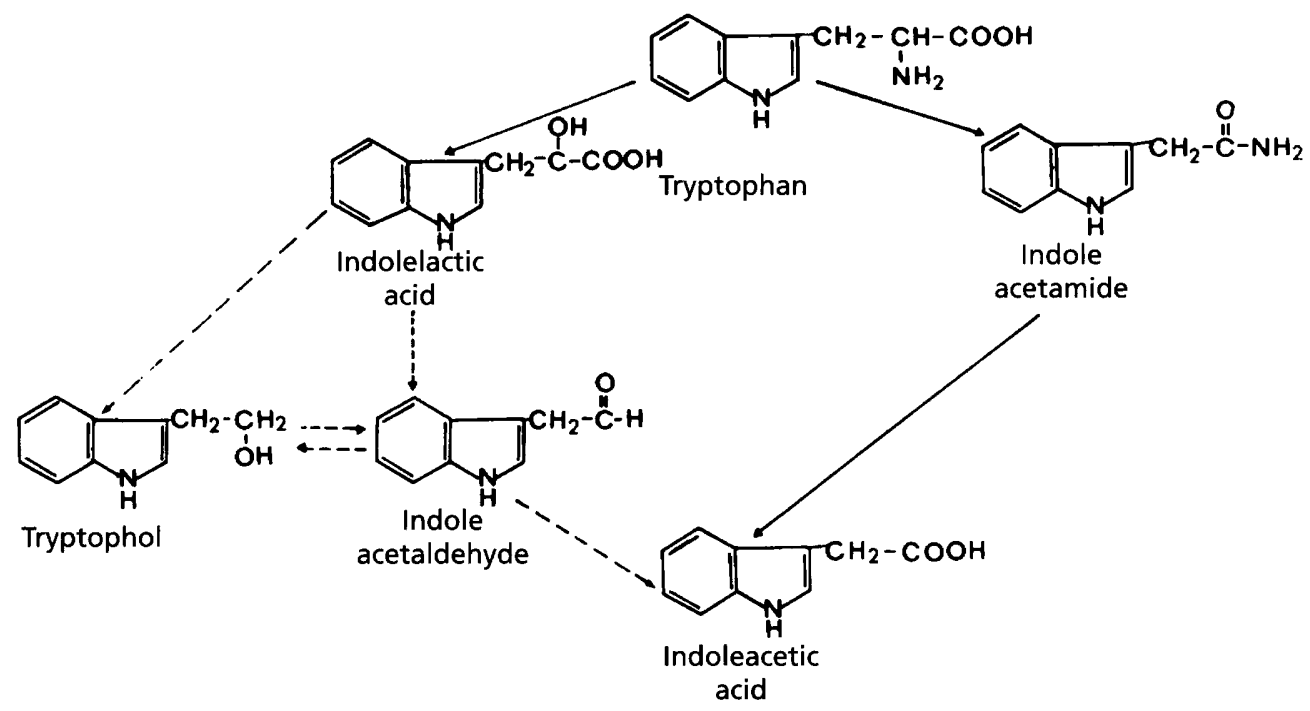

Fig. 4. Indoleacetamide pathway for IAA biosynthesis and other indole derivatives identified in S. violaceus during tryptophan metabolism. With the exception of IAAld all the other indole derivatives were identified. Solid lines indicate incorporation of radioactivity from Trp into indole derivatives whereas dashed lines signify hypothetical routes for transformation of the indole compounds into IAA.

and plants, such as Frankia sp. (Berry et al., 1989), Agrobacterium tumefaciens (Kutacek \& Rovenska,, 1990) and tomato (Gibson et al., 1972). In the latter, it has been proposed that ILA might act as precursor of IAA through a pathway initially involving decarboxylation of the lactic acid to produce IEt (Gibson et al., 1972). The IEt could then be oxidized to IAAld and IAA (Fig. 4). A similar pathway may exist in Streptomyces, and it could explain the detection of the two compounds. An alternative possibility is the existence of the IPvA pathway which has been reported in other bacteria (Manulis et al., 1991; Kutacek \& Rovenska, 1990). Even though we failed to detect the intermediates IPvA and IAAld, we did detect ILA, which is a common product of IPVA reduction, and IEt, which is a common product of IAAld reduction. It has been speculated that in micro-organisms, ILA has the characteristics of a secondary biologically inactive detoxification product of indole metabolism (Kutacek \& Rovenska, 1990). This might also explain the production of ILA during Trp metabolism in Streptomyces. In the $\left[{ }^{14} \mathrm{C}\right] \operatorname{Trp}$ incorporation experiments we could detect radioactivity in ILA but not in IEt, in spite of the fact that IEt was identified by GC-MS. It is possible that IEt is rapidly oxidized to IAAld so that it could be detected only when an excessive concentration of Trp was given to the cells. It should be pointed out that the final concentration of Trp in the feeding solution of the radioactive experiment was $1.6 \mathrm{mM}$ as compared to $7.6 \mathrm{mM}$ in the nonradioactive experiment.

Strains representing six different Streptomyces spp. were found to be capable of induced synthesis of IAA in the presence of Trp. Thus IAA production may be widespread among streptomycetes, which are often associated with plant roots or tubers. The possible relationship of IAA secretion to pathogenicity of Streptomyces strains on potato has yet to be proven by studying the pathogenicity of an IAA-lacking mutant. However, IAA might exhibit additional effects on plant tissue which could benefit Streptomyces multiplication in planta. Thus, exogenous IAA can induce plant-cell-wall loosening and membrane leakiness thereby stimulating the exudation of nutrients (Kundent \& Libbert, 1972). IAA-producing bacteria might therefore have an advantage over non-producing bacteria in acquisition of nutrients required for growth. It has been suggested that auxin and cytokinin concentration in plant tissues invaded by pathogens could affect the levels of hydrolytic enzymes such as chitinases and $\beta-1,3-$ glucanases, which are thought to be involved in plant defence responses (Shinshi et al., 1987). IAA was also found to suppress the hypersensitive response of host plants (Robinnete \& Matthysse, 1990). Thus IAA might alter plant defence responses, as a step toward optimizing the microbial interaction with host plants.

\section{ACKNOWLEDGEMENTS}

This work was supported by the Binational Agricultural Research and Development Fund (project US-2087-91).

\section{REFERENCES}

Badenoch-Jones, J., Summons, R. E., Entsch, B., Rolfe, B. G., Parker, C. W. \& Letham, D. S. (1982). Mass spectrometric identification of indole compounds produced by Rhizobium strains. Biomed Mass Spectrom 9, 429-437.

Barea, J. M. \& Brown, M. E. (1974). Effects on plant growth produced by Azotobacter paspali related to synthesis of plant growth regulating substances. $J$ Appl Bacteriol 37, 583-593.

Berry, A. M., Kahn, R. K. S. \& Booth, M. C. (1989). Identification of indole compounds secreted by Frankia HFP Arl3 in defined culture medium. Plant Soil 118, 205-209. 
Comai, L. \& Kosuge, T. (1983). The genetics of indoleacetic acid production and virulence in Pseudomonas savastanoi. In Molecular Genetics of the Bacteria-Plant Interactions, pp. 33-38. Edited by A. Puhler. Berlin: Springer-Verlag.

Doering-Saad, C., Kampfer, P., Manulis, S., Kritzman, G., Schneider, J., Zakrzewska-Czerwinska, J., Schrempf, H. \& Barash, I. (1992). Diversity among Streptomyces strains causing potato scab. Appl Environ Microbiol 58, 3932-3940.

Efremenkova, O. V., Anisova, L. N. \& Bastoshevich, Y. E. (1985). Regulators of differentiation in actinomycetes. Antibiot Med Biotekbnol 30, 687-707.

Ehmann, A. (1977). The Van Urk-Salkowski reagent - a sensitive and specific chromogenic reagent for silica gel thin-layer chromatographic detection and identification of indole derivatives. $J$ Chromatogr 132, 267-276.

Ek, M., Ljungquist, P. O. \& Stenstrom, E. (1983). Indole-3-acetic acid production by mycorrhizal fungi determined by gas chromatography-mass spectrometry. New Pbytol 94, 401-407.

El-Sayed, M. A., Valadon, L. R. G. \& El-Shanshoury, A. (1987). Biosynthesis and metabolism of indole-3-acetic acid in Streptomyces mutabilis and Streptomyces atroolivaceus. Microbios Lett 36, 85-95.

El-Shanshoury, A. R. (1991). Biosynthesis of indole-3-acetic acid in Streptomyces atroolivaceus and its changes during spore germination and mycelial growth. Microbios 67, 159-164.

Fett, W. F., Osman, S. F. \& Dunn, M. F. (1987). Auxin production of plant-pathogenic pseudomonads and xanthomonads. $A p p l$ Environ Microbiol 53, 1839-1845.

Gibson, R. A., Schneider, E. A. \& Wightman, F. (1972). Biosynthesis and metabolism of Indol-3-yl-acetic acid. II. In vivo experiments with ${ }^{14} \mathrm{C}$-labelled precursors of IAA in tomato and barley shoots. J Exp Bot 23, 381-399.

Gruen, H. E. (1959). Auxins and fungi. Annu Rev Plant Pbysioi 10, 405-440.

Hirata, S. (1959). Studies on the phytohormone in the malformed position of the diseased plants. Bull Miyazaki 5, 85-92.

Hooker, W. J. (1981). Common scab. In Compendium of Potato Diseases, pp. 33-34. Edited by W. J. Hooker. St Paul, MN: American Phytopathological Society.

Hopwood, D. A., Bibb, M. J., Chater, K. F., Kieser, T., Bruton, C. J., Kieser, H. M., Lydiate, D. J., Smith, C. P., Ward, J. M. \& Schrempf, H. (1985). Genetic Manipulation of Streptomyces. A Laboratory Manual. Norwich: John Innes Foundation.

Iskric, S. (1984). Metabolism of indolic compounds in plants. Period Biol 86, 153-162.

Kawaguchi, M., Fujioka, S., Sakurai, A., Yamaki, Y. T. R. \& Syono, K. (1993). Presence of a pathway for the biosynthesis of auxin via indole-3-acetamide in trifoliata orange. Plant Cell Physiol 34, 121-128.

Kosuge, T., Palm, C. J., Hutcheson, S. W., Glass, N. L. \& Yamada, T. (1985). pIAA1, a virulence plasmid in Pseudomonas savastanoi. In Plasmids in Bacteria, pp. 807-813. Edited by D. R. Helinski, S. N. Cohen, D. B. Clewell, D. A. Jackson \& A. Hollaender. New York: Plenum.

Kundert, R. \& Libbert, E. (1972). Interactions between plants and epiphytic bacteria regarding their auxin metabolism. 10. Exudation of amino acids and carbohydrates by corn shoots: a nutritive source of epiphytic bacteria. Biochem Physiol Pflanz 163, 524-535.

Kutacek, M. \& Rovenska, J. (1990). Auxin synthesis in Agrobacterium tumefaciens and in transformed tobacco tissue. In Molecular Aspects of Hormonal Regulation of Plant Development, pp. 111-124. Edited by M. Kutacek, M. C. Elliott \& I. Machackova. SPB Academic Publishing.

Lapwood, D. H. (1973). Streptomyces scabies and potato scab disease. In Actinomycetales: Characterization and Practical Importance, pp. 253-260. Edited by G. Sykes \& F. A. Skinner. London: Academic Press.

Liv, S. T., Perry, K. I., Schardi, C. I. \& Kado, C. I. (1982). Agrobacterium Ti plasmid indoleacetic gene is required for crown gall oncogenesis. Proc Natl Acad Sci US A 79, 2812-2816.

Manulis, S., Valinski, L., Gafni, Y. \& Hershenhorn, J. (1991). Indole-3-acetic acid biosynthetic pathways in Erwinia berbicola in relation to pathogenicity on Gypsopbila paniculata. Pbysiol Mol Plant Patbol 39, 161-171.

Offringa, I. A., Melchers, L. S., Regenburg-Tuink, A. J. G., Costantino, P., Schilperoort, R. A. \& Hooykaas, P. J. J. (1986). Complementation of Agrobacterium tumefaciens tumor-inducing aux mutant by genes from the $\mathrm{Tr}$-region of the $\mathrm{Ri}$ plasmid of Agrobacterium rbizogenes. Proc Natl Acad Sci US A 83, 6935-6939.

Robinnete, D. \& Matthysse, A. G. (1990). Inhibition by Agrobacterium tumefaciens and Pseudomonas savastanoi of development of the hypersensitive response elicited by Pseudomonas syringae pv. phaseolicola. J Bacteriol 172, 5742-5749.

Saotome, M., Shirahata, K., Nishimura, R., Yahaba, M., Kawaguchi, M., Syono, K., Kitsuwa, T., Ishii, Y. \& Nakamura, T. (1993). The identification of indole-3-acetic acid and indole-3-acetamide in hypocotyls of Japanese cherry. Plant Cell Pbysiol 34, 157-159.

Sekine, M., Ichikawa, T., Kuga, N., Kobayashi, M., Sakurai, A. \& Syono, K. (1988). Detection of the IAA biosynthetic pathway from tryptophan via indole-3-acetamide in Bradyrbizobium spp. Plant Cell Pbysiol 29, 867-874.

Shinshi, H., Mohenen, D. \& Meins, F., Jr (1987). Regulation of a plant pathogenesis-related enzyme: inhibition of chitinase mRNA accumulation in cultured tobacco tissues by auxin and cytokinin. Proc Natl Acad Sci US A 84, 89-93.

Tien, T. M., Gaskins, M. H. \& Hubbell, D. H. (1979). Plant growth substances produced by Azospirillum brasilense and their effect on the growth of pearl millet (Pennisetum americanum). Appl Environ Microbiol 37, 1016-1024.

Van Onckelen, H., Prinsen, E., Inze, D., Rudelsheim, P., Van Lijsebettens, M., Follin, A., Scell, J., Van Montagu, M. \& De Greef, J. (1986). Agrobacterium T-DNA gene 1 codes for tryptophan 2monooxygenase activity in tobacco crown gall cells. FEBS Lett 198, 357-360.

Wichner, S. \& Libbert, E. (1968). Interactions between plants and epiphytic bacteria regarding their auxin metabolism I. Detection of IAA-producing epiphytic bacteria and their role in long duration experiments on tryptophan metabolism in plant homogenates. Physiol Plant 21, 227-241.

Received 14 June 1993; revised 27 October 1993; accepted 15 November 1993. 